\title{
The Lavender Menace Comes to Melbourne: Feminism, Lesbianism, Place and Space in the 1970s
}

\author{
Jacquelyn Baker ${ }^{1}$
}

Deakin University, Geelong, Vic.

\begin{abstract}
This paper is part of a growing body of work that examines the Women's Liberation Movement (WLM) in Australia. Applying a spatial approach and drawing on safe space scholarship, I show that the way that notions of safety and separatism were perceived and articulated within place and space contributed to the tensions and conflict between heterosexual and lesbian feminists at the Women's Liberation Centre in Melbourne. Drawing on histories of the WLM and lesbian groups in Melbourne, through a close reading of Jean Taylor's political memoirs and the Melbourne Women's Liberation Newsletter and in examining a letter written by Zelda D'Aprano, this research contributes a new perspective to the heterosexual-lesbian split in Melbourne as it recognises the way that heterosexual and lesbian feminists had attempted to resolve their differences.
\end{abstract}

In 1976, Zelda D'Aprano wrote in 'sheer desperation' to the Melbourne Women's Liberation Newsletter $(M W L N) .{ }^{2}$ D'Aprano's letter, which was published in the April issue of the MWLN, conveyed her concern about the increase in lesbian feminists at the Women's Liberation Centre (WLC) as well as the increasing visibility of lesbian feminists in the Women's

1 Acknowledgements: My thanks to Joanna Cruickshank, the two anonymous reviewers, Alexandra Ciaffaglione and Hannah Viney for their kind and constructive feedback that helped to strengthen this article. In part, this article has drawn on the research I have conducted as part of my $\mathrm{PhD}$ research. I would like to acknowledge that my $\mathrm{PhD}$ research has been funded by an Australian Government Research Training Program Scholarship.

2 Zelda D'Aprano, 'Sisters Speak', Melbourne Women's Liberation Newsletter, April 1976, 1. Archive file no. 305.4209945 WOME, University of Melbourne Archives, Melbourne. 
Liberation Movement (WLM) in Melbourne. ${ }^{3}$ In her letter, D'Aprano described the WLC as a place of 'warmth compassion and understanding' and as a place 'all women could enter' despite the 'structural limitations' of the building. ${ }^{4}$ However, D'Aprano worried about the 'inner turmoil that seems to be seething in and around' the WLC, which she attributed to the presence of lesbian feminists. ${ }^{5}$ D'Aprano also expressed concern about the joint mailout of Lesbian News and the MWLN. ${ }^{6}$ The MWLN ran its first edition in February 1972 with subsequent editions printed and distributed monthly; it was considered by Jean Taylor to be an 'invaluable source of communication and a necessary resource for information and events.' ${ }^{7}$ While the $M W L N$ was an established newsletter, Lesbian News was just finding its feet and building a readership, thus the decision was made in 1976 for the combined mailout of these two newsletters so that the Lesbian News collective could save money. ${ }^{8}$ D'Aprano believed that the joint mailout would 'come as a great shock [to women new to the WLM] and more likely turn them away from the movement' and she wondered is this the way we see the solution in changing society, dissipating our women's energy to save a few dollars'?

D'Aprano's concern echoed a similar fear conveyed by Betty Friedan in 1970. Friedan - who was a well-known and highly regarded feminist and the leader of the National Organisation for Women (NOW) - was concerned about the increasing visibility of lesbian feminists and declared that lesbian feminists were 'a "lavender menace" that was threatening' the WLM in the United States. ${ }^{10}$ Some heterosexual feminists who were part of the 'older generation' of the WLM-like D'Aprano and Friedanthought that the WLM would be 'stigmatised if it were associated with lesbians' ${ }^{11}$ Linda Gordon noted that the concept of women's liberation enabled women to come out as lesbian en masse. ${ }^{12}$ The increasing number

3 While the WLC was also referred to by some as the 'Women's Centre', for the sake of consistency I will refer to the centre as the Women's Liberation Centre.

4 D’Aprano, 'Sisters Speak', 1.

5 Ibid.

6 Ibid., 3.

7 Jean Taylor, Brazen Hussies: A Herstory of Radical Activism in the Women's Liberation Movement in Victoria 1970-1979 (Melbourne: Dyke Books Inc., 2009), np.

8 Taylor, Brazen Hussies, np.

9 D'Aprano, 'Sisters Speak', 3.

10 Linda Gordon, 'The Women's Liberation Movement', in Feminism Unfinished, ed. Dorothy Sue Cobble, Linda Gordon and Astrid Henry (New York: Liveright Publishing Corporation, 2014), 91.

11 Ibid.

12 Ibid. 
of lesbian feminists in the WLM in the US led to the inclusion of lesbian feminist theorising in the development of women's liberation theory. In particular, lesbian feminist theory encouraged women's liberationists to question assumptions rooted in heteronormativity, such as what was considered normal or natural in sex and the family unit, and enabled women's liberationists to reframe 'marriage as an option, not a necessity'. ${ }^{13}$ In addition, Dana R. Shugar contends that lesbian feminists helped to reshape and redefine the concept of women's community and separatism for women's liberationists in the early 1970s. ${ }^{14}$ Friedan renounced her stance a year later when a recently formed group of lesbian feministsknown then as Lavender Menace and later as radicalesbians-took to the stage at the Congress to Unite Women with 'lavender menace' on their t-shirts. ${ }^{15}$ This act was met with cheering and laughter from the audience. Lavender Menace then facilitated a speak-out and encouraged audience participants to discuss prejudices against lesbians in feminism. When Lavender Menace opened the microphone to the floor, dozens of women reportedly 'thronged' to the stage to voice their support of lesbian feminists, to share their experiences and to 'come out' as lesbian or bisexual. ${ }^{16}$ This was a defining moment for the WLM in the US as it established that lesbians were not a menace but were indeed part of the WLM.

Like Friedan, D'Aprano was a well-known and highly regarded figure. D'Aprano was an active participant in the Communist Party and the union and women's movements in Melbourne. Her most recognised contribution to women's liberation was her chain-in to the Commonwealth Building on 21 October 1969. The aim of this protest was to draw attention to an equal pay case and was ultimately one of the events that kick-started the WLM in Melbourne. ${ }^{17}$ D'Aprano was accompanied by a number of other women, who are unnamed in her autobiography and who walked up and down with the placards which called upon the government to grant women equal pay'. ${ }^{18}$ A photograph

13 Ibid.

14 Dana R. Shugar, Separatism and the Women's Community (Nebraska: University of Nebraska Press, 1995), 25.

15 Ibid. The radicalesbians wrote The Woman-Identified Woman, a 10-page manifesto that was distributed at the Congress to Unite Women. This manifesto became a seminal text in lesbianism and lesbian feminism.

16 Ibid.

17 Marilyn Lake, Getting Equal: The History of Australian Feminism (Sydney: Allen \& Unwin 1999), 217.

18 Zelda D’Aprano, Zelda (North Melbourne: Spinifex, 1995), 171. 
of D'Aprano chained to the Commonwealth Building piqued the interest of two school teachers, Alva Geikie and Thelma Solomon. Geikie phoned D'Aprano to congratulate her on her successful protest and to request to be part of any future chain-ins and actions. ${ }^{19}$ D'Aprano, Geikie and Solomon would later go on to co-organise a chain-in to the Arbitration Court on 31 October 1969, attend numerous women's meetings together and to form the Women's Action Committee (WAC). ${ }^{20}$

Throughout 1971, WAC organised letter-writing campaigns, gave talks, created their own consciousness-raising group, demonstrated at a Miss Teenage Quest and 'organised the second national Women's Liberation Conference on women at work and women in the trade unions. ${ }^{21}$ D'Aprano described 1972 as the 'second year of the movement' and contended that 'women began pouring in'. ${ }^{22}$ Women and men were phoning D'Aprano and fellow WAC member Bon Hull for advice relating to issues such as abortion and marital problems. ${ }^{23}$ The number of phone calls was becoming quite a problem and was making D'Aprano and Hull feel 'desperate'. ${ }^{24}$ It was clear to them that Melbourne needed a 'centre where women could meet and make contact'. ${ }^{25}$ The impending visit of Germaine Greer to Melbourne 'added further impetus' to establishing a centre. ${ }^{26}$ Victoria's first WLC opened in March 1972 at 16 Little La Trobe Street, Melbourne. ${ }^{27}$

It is in this context of D'Aprano's significant contributions to the women's and union movements, as well as her influence and standing within the WLM in Melbourne, that I will analyse her letter. In this analysis, it is not my intention to 'call-out' D'Aprano or to suggest that this tension between D'Aprano and lesbian feminists persisted beyond the 1970s. Rather, it is in the context of her remarkable legacy that D'Aprano's letter offers a valuable object of analysis, particularly in examining the relationship between heterosexual and lesbian feminists. The purpose of my analysis is to uncover how notions of safety and separatism were perceived and articulated within the place and space of the WLC and to

19 Ibid., 172.

20 Ibid., 174, 190-91.

21 Taylor, Brazen Hussies, np.

22 D’Aprano, Zelda, 236.

23 Ibid., 234-35.

24 Ibid., 235.

25 Ibid., 236.

26 Ibid.

27 Taylor, Brazen Hussies, np. 
understand how these notions contributed to the tensions and conflict between heterosexual and lesbian feminists in the WLM in Melbourne in the 1970s. The WLC offers a site through which we may better understand the interactions between heterosexual and lesbian feminists. Furthermore, this research offers a new perspective on the heterosexual-lesbian split that affected the WLM in Melbourne and demonstrates that conflict could be constructive in the creation and maintenance of the women's liberation places and spaces in Melbourne.

\section{Historical Background}

Margaret Henderson noted that, in the late 1990s, there was an emergence of a 'significant number of feminist narratives' that historicised the secondwave women's movement in Australia and that, during this period, the first 'full length' histories were published. ${ }^{28}$ Judith Ion contended that while 'full length publications celebrating the longevity of the Australian movement have been slow to arrive', Australian feminists had not 'totally neglected to record the movement's past'. ${ }^{29}$ Ion maintains that 'since the movement's early days occasional (usually local) histories have been produced'. ${ }^{30}$ In building on the work of Ion, Henderson contends that early histories of the WLM have mostly taken the form of articles or book chapters. ${ }^{31}$

In reflecting on the historical narratives that were published in the 1980s and 1990s, Henderson felt that, as a participant of the movement in Brisbane, she "hardly recognised the strange tales they told of the

28 Margaret Henderson, Marking Feminist Times: Remembering the Longest Revolution in Australia (Bern: Peter Lang, 2006), 13; Judith Ion, 'Unravelling Our Past: Questions of Feminism, History and Memory', Australian Feminist Studies, 13, no. 27 (1998): 108. For full-length histories, see Gisela Kaplan, The Meagre Harvest: The Australian Women's Movement, 1950s-1990s (Concord: Paul and Co., 1996); Jean Curthoys, Feminist Amnesia: The Wake of Women's Liberation (London: Routledge, 1997); Chilla Bulbeck, Living Feminism: The Impact of the Women's Movement on Three Generations of Australian Women (Cambridge: Cambridge University Press, 1997); Lake, Getting Equal.

29 Ion, 'Unravelling our Past', 108. See, for example, Women's Liberation Halfway House Collective, Herstory of the Halfway House: 1974-1976 (Melbourne: Women's Liberation Halfway House Collective, 1977).

30 Ibid.

31 Margaret Henderson, 'Legends of the Rise and of the Fall: Towards a Poetics of Histories of the Australian Women's Movement', Clio: A Journal of Literature, History and the Philosophy of History, 31, no. 3 (2002): 301. For example, see Ann Curthoys, For and Against Feminism: A Personal Journey into Feminist Theory and History (Sydney: Allen \& Unwin, 1998). 
movement: often pessimistic, defeated and self-punishing. ${ }^{32}$ Ion observed that this scholarship, in part, tended to focus on organisations, events or specific moments and that there was a distinct lack of work that examined the movement over 'time and place'. ${ }^{33}$ Thus far, I have only been able to identify two publications that were published during the 1980s and 1990s that trace the second-wave women's movement in Melbourne over time: a chapter titled 'The Women's Movement: Then and Now' in Marian Sawer and Marian Simms' A Women's Place: Women and Politics in Australia, which, in part, follows the development of the WLM and the Women's Electoral Lobby in Melbourne and examines the differences in political ideologies held by the two groups, and Katy Reade's article, 'The Discourses of Crisis in the Women's Liberation Movement and the Women's Electoral Lobby', which traces the development of tensions, conflicts and power struggles that led to the splintering of the WLM in Melbourne. ${ }^{34}$ Since the 1990s, Jean Taylor has written the majority of work that traces the WLM and lesbian movement in Melbourne from the 1970 s to the 1990 s. ${ }^{35}$

Thus far, historians have yet to analyse the WLM in Australia through a spatial lens. This is in contrast to historians of the WLM in the US, who have demonstrated—as will be discussed — that a spatial approach can broaden understandings of how attempts to create and cultivate women's liberation places and spaces contributed to conflict and tension between women's liberationists and feminists, as well as how women's liberationists and feminists worked together to overcome these challenges. In building on the scholarship that has traced the development of the WLM in Melbourne over time and in drawing on a spatial approach, this

32 Henderson, Marking Feminist Times, 13. See also Margaret Henderson and Margaret Reid, "II's Not that Bloody Far from Sydney": Notes Towards a Semiotic History of the Brisbane Women's Movement, 1973-1983', Australian Feminist Studies, 19, no. 44 (2004): 160.

33 Ion, 'Unravelling our Past', 108.

34 Marian Sawer and Marian Simms, A Woman's Place: Women and Politics in Australia (Sydney: Allen \& Unwin, 1984), 171-96; Katy Reade, 'The Discourses of Crisis in the Women's Liberation Movement and the Women's Electoral Lobby in Melbourne in the Late 1970s', Lilith: A Feminist History Journal, no. 9 (1996): 125-45.

35 Taylor, Brazen Hussies; Jean Taylor, Stroppy Dykes: Radical Lesbian Feminist Activism in Victoria during the 1980s (Melbourne: Dyke Books Inc., 2012); Jean Taylor, Lesbians Ignite! In Victoria in the 1990s (Melbourne: Dyke Books Inc., 2016). Taylor's books are political memoirs. For scholarship that examines the movement over time and place in Sydney and Brisbane, see Louise R. Mayhew "'Volatile, Feral and Glamorous": Australia's Women's Warehouse', AM: Journal of Art and Media Studies, no. 8 (2015): 29-34; Henderson and Reid, "It's Not that Bloody Far from Sydney"'. 
paper will broaden understandings of interactions, tensions and conflicts between heterosexual and lesbian feminists within the place and space of the WLC.

\section{Spatial Analysis: Safe Space and Reframing Safety}

Critics of spatial analysis have pointed to the ways that imprecise terminology' has undermined the implementation of this particular methodology; thus, I will foreground further discussion with definitions of place and space. ${ }^{36}$ According to John Agnew, there are three definitions of place. Place can refer to coordinates on a map, 'material settings for social relations' and a 'sense of place', which is the relationship that people have to place. ${ }^{37}$ Space, as defined by Paul Carter, is 'transformed symbolically into place, that is, with history'. ${ }^{38}$ In building on Carter's definition, Lisa Weems describes space as 'not a refuge ... outside of the historical, political and social networks of meaning and action governed by asymmetrical relations of power'. ${ }^{39}$ Weems contends that 'multiple and competing past histories of association with space always intermingle with feelings of safety'. ${ }^{40}$ Furthermore, Kathryne Beebe, Angela Davis and Kathryn Geadle define space as a site 'where issues of sexuality, race, class and gender-amongst a myriad of other power/knowledge struggleswere sited, created and fought out' ${ }^{41}$ In this research, the WLC as a place refers to the various addresses of the WLC throughout the 1970s as well as the sense of place that lesbian and heterosexual women's liberationists and feminists felt towards the WLC. The WLC as a space builds on the associations, or sense of place, that lesbian and heterosexual feminists had to the WLC and how these competing associations had affected the way that the WLC was perceived as 'safe'.

36 Beat Kumin and Cornelie Usborne, 'At Home and in the Workplace: A Historical Introduction to the Spatial Turn', History and Theory, 52, no. 3 (2013): 317.

37 Charles W. J. Withers, 'Place and the "Spatial Turn" in Geography and History', Journal of the History of Ideas, 70, no. 4 (2009): 639-40.

38 Paul Carter, The Road to Botany Bay: An Essay in Spatial History (London: Faber and Faber, 1987), np, in Ibid., 647.

39 Lisa Weems, 'From "Home" to "Camp": Theorising the Safety of Space', Studies in Philosophy and Education, 29, no. 6 (2010): 561-62.

40 Weems, "From "Home" to "Camp", 561.

41 Kathryne Beebe, Angela Davis and Kathryn Geadle, 'Introduction: Space, Place and Gendered Identities: Feminist History and the Spatial Turn', Women's History Review, 21, no. 4 (2012): 524. 
Contemporary scholarship on the concept of 'safe space' has encouraged me to ask different questions of the feminist past. While 'safe space' is not a term that women's liberationists in Melbourne would have used, contemporary researchers contend that the concept of 'safe space' emerged from the practices of those who participated in the WLM, as well as gay liberation and anti-racist movements. ${ }^{42}$ Rosemary Clark-Parsons and the Roestone Collective draw on Moira Kenney to explain that women's liberation safe spaces not only 'promoted freedom from violence and harassment', but also 'provided a certain licence to speak and act freely, form collective strength, and generate strategies for resistance. ${ }^{43}$ For ClarkParsons, the 'archetypal feminist safe space was the separatist, womenonly, consciousness-raising group'. ${ }^{44}$ The formation of consciousnessraising groups as well as the creation of separatist and women-only spaces can be seen as part of a wider strategy of the WLM, and the broader second-wave women's movement, to create 'women's spaces'. ${ }^{45}$ Finn Enke noted that all across the United States women were creating and taking over space: women were creating women's health clinics and refuges and reclaiming space in bars, sporting fields and street theatre. Furthermore, Enke maintains that these second-wave women's spaces 'became sites of protest against the gendered exclusions of public geography, and also meeting grounds in which multiple cultures of feminist and lesbian activism merged'. ${ }^{46}$ Like Enke, the Roestone Collective also point to the way that women's liberationists had attempted to reclaim space and to create their own space and draw on the examples of the Take Back the Night march in Washington, DC, in September 1981 and the formation of 'lesbian lands' - such as Kvindelandet in Denmark-in the 1970s and 1980s, respectively. ${ }^{47}$ Women's liberationists and second-wave feminists

42 Roestone Collective, 'Safe Space: Towards a Reconceptualization', Antipode, 46, no. 5 (2014): 1346. See also Rosemary Clark-Parsons, 'Building a Digital Girl Army: The Cultivation of Feminist Safe Space Online', New Media \& Society, 20, no. 6 (2018): 2128-29. The Roestone Collective consists of two geographers, Heather Rosenfeld and Elsa Noterman. Both the Roestone Collective and Rosemary Clark-Parsons draw on Moira Kenney, Mapping Gay LA: The Intersection of Place and Space (Philadelphia: Temple University Press, 2001).

43 Kenney, Mapping Gay LA, 24, in Clark-Parsons, 'Building a Digital Girl Army', 2128; Roestone Collective, 'Safe Space', 1346.

44 Clark-Parsons, 'Building a Digital Girl Army', 2128.

45 Finn Enke, 'Smuggling Sex Through the Gates: Race, Sexuality, and the Politics of Space in Second Wave Feminism', American Quarterly, 55, no. 4 (2003): 636.

46 Ibid.

47 Roestone Collective, 'Safe Space', 1351, 1353-54. Further examples of women's lands include Amazon Acres in Australia and Oregon Women's Land Trust in the United States. 
recognised that being 'woman' was political. Enke contends that, in part, their 'activism depended on ... taking over and re-defining public places and on challenging sexist geographies'. ${ }^{48}$

In response to the way that the concept of 'safe space' has been overused, the Roestone Collective have retheorised and reconceptualised 'safe space'. In particular, the Roestone Collective examined the relational work that goes into creating and maintaining a safe space and have understood safe spaces as more than just responding to a definition of 'unsafe' as a 'static and predefined category. ${ }^{49}$ The Roestone Collective found that the categories of 'safe' and 'unsafe' are 'socially produced and context dependent' and that safe spaces speak to social constructions of safety that stem from 'patriarchal, heteronormative, racialized and classed' constructions. ${ }^{50}$ In building on the Roestone Collective's reconceptualisation of safety, Ruth Lewis, Elizabeth Sharp and Rhiannon Redpath reconceptualise safety as moving beyond a static understanding of safety from (for example, the safety from physical or sexual violence and harassment) to broadening the definition of safety as the safety to (such as the safety for women to be themselves and to 'speak and be heard, to learn and develop cognitively, to be emotionally expressive'). ${ }^{51}$

Scholarship on the contemporary usage of 'safe space' also builds on these attempts to redefine safety. Jill Wilkens's feminist study of social groups and networks for older women in England who identified as lesbian or bisexual found that these 'groups were experienced as safe spaces offering friendship and company, acting as forums for socialising, affirmation, belonging and the alleviation of loneliness and isolation'. ${ }^{52}$ However, Wilkens also found that women who met in places and spaces that were 'shared with other community groups spoke less positively about their surroundings and did not express the same sense of belonging or safety'. ${ }^{53}$ While group differences can affect how safety is experienced in place and space, Angela M. Carter's research, which considers debates over the inclusion of trigger

48 Enke, 'Smuggling Sex Through the Gates', 636.

49 Roestone Collective, 'Safe Space', 1347.

50 Ibid., 1350.

51 Ruth Lewis, Elizabeth Sharp, Jenni Remnant and Rhiannon Redpath, "Safe Spaces”: Experiences of Feminist Women-only Space', Sociological Research Online, 20, no. 4 (2015): 5.

52 Jill Wilkens, 'The Significance of Affinity Groups and Safe Spaces for Older Lesbians and Bisexual Women: Creating Support Networks and Resisting Heteronormativity in Older Age', Quality in Aging and Older Adults, 17, no. 1 (2016): 26, 33-34. Over a third of Wilkens's participants had played key roles in setting up and establishing feminist lesbian-only or lesbian and bisexual groups.

53 Ibid., 31. 
warnings in class syllabi, revealed that limiting difference can also be disadvantageous. ${ }^{54}$ Carter found that while the incorporation of safe space practices and trigger warnings may be beneficial in an educational setting as it helps to recognise students' 'lived experiences', she also contends that removing difference to 'ensure safety in a feminist classroom also risk[s] denying difference and suppressing pedagogically valuable conflict'. ${ }^{55}$ Furthermore, Carter, who builds on the work of bell hooks, also maintains that safety, when invoked by the majority, can be used to 'silence the voices of "those on the margins" who spoke about social injustice'. ${ }^{56}$ Like Carter, the Roestone Collective also found that when they examined the relational work that goes into creating and maintaining a safe space, safe spaces do "indeed reinforce other "common problems" that exist in the wider community or society-such as homophobia. They contend that it is through attempting to understand how individuals maintain safe spaces that we can understand how individuals are able to 'recognise and negotiate sometimes deeply problematic differences' that occur within safe space. ${ }^{57}$

Contemporary scholars often describe separatism as a quintessential quality of a women's liberation safe space. Indeed, as Shugar has noted, a separatist, women-only community was experienced as a safe space as 'women could join to plan revolutionary action' and it was believed that a women-only community that was separate from men, and the values that are associated with men, 'would lead to the only viable feminist freedom'. ${ }^{58}$ However, this notion placed an emphasis on the bonds between women and implied that women would not, and could not, harm other women in the same way that a 'male-dominated mainstream society' harmed women. ${ }^{59}$ Like safe spaces, women-only spaces replicated some of the problems that existed in the wider community, and, as Shugar observes, some women soon discovered that separatist, women-only communities, groups or spaces that proclaimed unity through the catchcry 'all women' were not as inclusive as they appeared to be. ${ }^{60}$

54 Angela M. Carter, 'Teaching with Trauma: Trigger Warnings, Feminism and Disability Pedagogy', Disability Studies Quarterly, 35, no. 2 (2015): np.

55 Ibid. This finding builds on the work of Berenice Malka Fisher. See Berenice Malka Fisher, No Angel in the Classroom: Teaching through Feminist Discourse (Lanham: Rowman \& Littlefield Publishers, Inc., 2001).

56 Carter, 'Teaching with Trauma'.

57 Roestone Collective, 'Safe Space', 1347-48.

58 Shugar, Separatism and the Women's Community, 15.

59 Ibid.

60 Ibid. 
Like their counterparts in the United States, women's liberationists and second-wave feminists in Australia also sought to reclaim and recreate space. In Melbourne, women's liberationists held actions on trams, in pubs and at beauty contests, held demonstrations in the street, formed consciousness-raising and action groups, created women-only health and refuge services and cultivated their own centres and meetings places where women could gather and plan women's liberation actions, such as the WLC. ${ }^{61}$ Contemporary safe space scholarship encouraged me to examine the work that women's liberationists put into cultivating their places and spaces and to consider how group differences, as well as notions of separatism, women-only and safety, had affected perceptions of a women's liberation place as a safe space. While scholarship that traces the history of the concept of 'safe space' appears to be limited to the context of the United States, my paper is part of a burgeoning body of work that is questioning and considering the significance of the relationship between space, feminism and the movement of women in and out of place and space. ${ }^{62}$

\section{Non-political and Political Lesbian Groups in Melbourne, 1940-70s}

Lucy Chesser contends that, since the 1940s, lesbians were part of mixed social networks that had formed based on a shared interest in art, theatre, sport or participation in the army. In addition to these social groups, a small number of hotels and cafes, such as Prompts Corner and Val's Coffee Shop, attracted a 'strong lesbian clientele'. ${ }^{63}$ During the mid1960s, a mixed group of lesbians and gay men formed Checkmates, which functioned as a social club. Checkmates was best known for their successful public dances, which were 'advertised by word of mouth' and were attended by 'three or four hundred lesbians and gay men'. ${ }^{64}$ By the late 1960s, the first lesbian, and openly homosexual organisation, was

61 Examples of women's liberation health and refuge services in Melbourne include the Women's Health Centre, the Rape Crisis Centre and the Women's Liberation Halfway House.

62 Finn Enke, Finding the Movement (Durham and London: Duke University Press, 2007), 5-6, in Sherna Berger Gluck, 'Has Feminist Oral History Lost its Radical/Subversive Edge?', Oral History, 39, no. 2 (2011): 68.

63 Lucy Chesser, 'Australasian Lesbian Movement: "Claudia’s Group" and Lynx: "Non-Political" Lesbian Organisation in Melbourne, 1969-1980', Hecate, 22, no. 1 (1996): np.

64 Ibid. 
formed in Melbourne. Inspired by the Daughters of Bilitis in the United States, Marion Paull and Claudia Pearce formed the Daughters Of Bilitis in Melbourne. In 1970, Daughters Of Bilitis broke away from the American organisation and renamed themselves the 'Australasian Lesbian Movement'. The Australasian Lesbian Movement aimed to be a 'political extension to the increasingly advanced status of lesbian subculture in Melbourne in this period'. ${ }^{65}$ However, the Australasian Lesbian Movement's political goals were restricted by the group's internal struggle between seeking to provide an alternative social group for lesbians who were not comfortable with the hotel scene and their attempt to be a public group that aimed to provide education and an understanding of lesbians to a 'heterosexual society in order to achieve tolerance and understanding' ${ }^{66}$ Over time, the demographic of the Australasian Lesbian Movement shifted and by 1972 the organisation was less politically motivated and served more as 'an alternative to lesbian activism within the women's movement'. ${ }^{67}$ When the Australasian Lesbian Movement folded in 1973, those who did not feel comfortable taking part in the political activism of gay and women's liberation continued to meet and formed a group called Lynx, which served as a 'contact point for "non-radical" lesbians' and offered an entry point into 'lesbian and gay subcultures'. ${ }^{68}$

Chris Sitka has recorded that politically active lesbians were often unsure of whether they should be more 'aligned' with the WLM or the Gay Liberation Movement. ${ }^{69}$ In Melbourne, some lesbian feminists had experienced a vast amount of 'sexism of the men' at the Gay Liberation Centre, which was located in Davis Street. ${ }^{70}$ According to Robert Reynolds, despite groups such as CAMP, who wanted to 'demonstrate to the wider public that homosexuals and lesbians were no oddball minority', the wider public continued to confuse and conflate the experiences of gay men with lesbians. ${ }^{71}$ It can be interpreted that this 'fundamental gendered shortcoming' reflected, as Dennis Altman contended, the 'inferior position of women in our society', which could have been another factor that led some lesbian feminists to become more aligned with the WLM

65 Ibid.

66 Ibid.

67 Ibid.

68 Ibid.

69 Chris Sitka, 'A Radicalesbian Herstory', 1988, np. Archive file no. 175, Australian Queer Archives, Melbourne.

70 Ibid.

71 Robert Reynolds, From Camp to Queer (Carlton: Melbourne University Press, 2002), $26,47$. 
rather than the gay liberation movement. ${ }^{72}$ Lesbian feminists wanted to create their own identities and political agendas separate from gay men. Indeed, Rebecca Jennings' research reveals that the WLM's emphasis on the necessity of women-only spaces and activism meant that the WLM not only 'offered an attractive and supportive space for women who already identified as lesbians', but that the women-only spaces and places of the movement provided some women the opportunity to 'explore their sexuality' separate from men. ${ }^{73}$

\section{The Development of Women's Liberation and Lesbian Feminism in Melbourne}

Katy Reade has identified two threads as the beginning of the WLM in Melbourne. The first thread was D'Aprano's chain-in and the formation of WAC. Reade observed that the second thread was the formation of women's liberation university groups at La Trobe, Monash and Melbourne in $1970 .{ }^{74}$ WAC and the university groups had formed, seemingly unbeknownst to each other, during a similar period of time and with a significant focus on women and class-based oppression: the former as a result of their lived experience in the workforce and the union movement and the latter through their university education and increasing awareness of communism and socialism. The first contact between these two strands occurred when the University of Melbourne group invited WAC to a consciousness-raising session. ${ }^{75}$ According to Reade, Thelma Solomon recalled that D'Aprano was worried 'about these young educated women whom she had assumed were different to her' ${ }^{76}$ Eventually, WAC did attend the University of Melbourne women's liberation group's consciousness-raising session and it was at this session that D'Aprano managed to 'overcome her ... "worries" about the university-based women's liberation groups. ${ }^{77}$

72 Dennis Altman, Homosexual: Oppression and Liberation (St Lucia: University of Queensland Press, 2012), 26, 92.

73 Rebecca Jennings, 'Creating Feminist Culture: Australian Rural Lesbian Separatist Communities in the 1970s and 1980s', Journal of Women's History, 30, no. 2 (2018): 89.

74 Katy Reade, 'Recognising and Reconstructing an Identity: The Beginnings of the Women's Liberation Movement in Melbourne', Melbourne Historical Journal, 24 (1996): 30.

75 Ibid., 42.

76 Ibid.

77 Ibid. 
As the WLM in Melbourne grew, D'Aprano and Hull recognised the need for a centre. The WLC opened in March 1972 at 16 Little La Trobe Street in the CBD. ${ }^{78}$ D'Aprano felt that the WLM in Melbourne was 'official' when she saw that the Centre's phone number was registered as the 'Women's Liberation Movement' in the phone book. She reflected that as consciousness-raising groups were growing across Melbourne, 'there was no longer any need' for the WAC and the group 'disbanded'.$^{79}$ The WAC women continued to be active in the WLM in Melbourne and joined various other groups. Taylor has recorded that in the beginning the WLC aimed to 'act as a focus for the diverse WLM groups and to provide a phone information, support and referral service as well as a central meeting place to coordinate various activities' ${ }^{80}$ The groups that met at the building included the MWLN Committee, as well as various action groups committed to issues such as equal pay, child care and abortion. In addition to providing a central meeting place, the WLC also provided women with information about women's liberation and feminist theories, meetings, actions and fundraisers. Taylor described the outside of the Little La Trobe Street WLC building as 'unprepossessing'. ${ }^{81}$ It was a 'twostoried brick building right on the street'. ${ }^{82}$ Upon entering the purple front door, one would come across:

a steep flight of stairs leading to a large open space and an assortment of second-hand furniture, a desk with a phone, and a typewriter, open shelves with magazines, articles, and newsletters for sale, the gestetner, and eventually a small library. ${ }^{83}$

According to Taylor, the conflicts between women at the WLC at 16 Little La Trobe Street were minimal. The only major issue of concern was whether or not to allow men into the WLC. In the August 1972 issue of the MWLN, the question of whether the WLC was open to men, as 'men would like to assist the movement', was suggested as a topic of discussion for the groups at the WLC. ${ }^{84}$ Taylor recalled that this conflict 'got short shift' as the WLC was 'for womyn by womyn and as such womyn only

\footnotetext{
78 Taylor, Brazen Hussies, np.

79 Ibid.

80 Ibid.

81 Ibid.

82 Ibid.

83 Ibid. Archive file no. 305.4209945 WOME, University of Melbourne Archives, Melbourne.

84 Anon, 'Is the Centre Open to Men?', Melbourne Women's Liberation Newsletter, August 1972, 3.
} 
space as far as most of the womyn there were concerned' ${ }^{85}$ However, in the November 1973 issue of the MWLN, Alice wrote-in response to pieces by Adrianna in the July issue and Kathy in the August issue-that she thought that 'men are not the enemy' and that men, like women, were 'losers in the present scheme of society'. ${ }^{86}$ While Alice's article can be seen as part of the debate over whether men were allowed to enter the WLC, it also demonstrates how separatist, or women-only, strategies were perceived by some women's liberationists as anti-male. Other problems for the women's liberationists and feminists at the WLC from 1972-74 were recorded in the MWLN and related to finance, cleaning the WLC, alienation, as well as the purpose of the Coordinating Committee. ${ }^{87}$

The Coordinating Committee was an action group with a rotating membership and their responsibilities included overseeing the 'day-today events that affect the Movement' and the WLC as well as calling the General Meetings. ${ }^{88}$ The first General Meeting was held in 1972 at the WLC. At first, they were held once a month and, eventually, twice a month. ${ }^{89}$ According to Taylor, the purpose of the General Meetings was to provide a form of:

communication between the various activist collectives, area groups and individual groups ... General Meetings were designed to discuss issues, co-ordinate actions, organise demonstrations, hear reports from various groups, formulate theory, work out finances, and generally make policy about WLM activities. All womyn were welcome to attend..$^{90}$

The minutes of the General Meetings were printed in the MWLN, which meant that women who were unable to attend the General Meetings would be able to access information about decisions, events and other important

85 Taylor, Brazen Hussies, np. Archive file no. 305.4209945 WOME, University of Melbourne Archives, Melbourne.

86 Alice, 'Are Men The Enemy?', Melbourne Women's Liberation Newsletter, November 1973, 4. Archive file no. 305.4209945 WOME, University of Melbourne Archives, Melbourne.

87 Anon, 'We are Going to be in Bad Trouble ...', Melbourne Women's Liberation Newsletter, June 1972, 1; Anon, 'Sisters! ...', Melbourne Women's Liberation Newsletter, August 1972, 1; Anon, 'To Allow for More Discussion ...', Melbourne Women's Liberation Newsletter, February 1973, 2; Ky, 'At the General Meeting ...', Melbourne Women's Liberation Newsletter, March 1973, 2. Archive file no. 305.4209945 WOME, University of Melbourne Archives, Melbourne.

88 Anon, 'What Is the Co-ordinating Committee?' Melbourne Women's Liberation Newsletter, September 1973, 14. Archive file no. 305.4209945 WOME, University of Melbourne Archives, Melbourne.

89 Anon, 'Coming Events', Melbourne Women's Liberation Newsletter, May 1973, 15.

90 Taylor, Brazen Hussies, np. 
announcements. Ultimately, the General Meetings were perceived as 'the central point of decision making for the WLM as a whole', and so became the subject of much debate in 1976 as part of the wider discussion relating to the purpose and function of the WLC. ${ }^{91}$

Taylor describes 1973 as the year that lesbian feminists made their collective presence felt'. ${ }^{92}$ The first mention of lesbian feminists that I have found in the MWLN was in the May 1973 issue. An article entitled 'Gay Sisters' detailed how a group of 'sisters from gay liberation' attended a General Meeting on 8 April 1973 in order to 'establish a place in the 'WLM in Melbourne'. ${ }^{93}$ These 'sisters' were part of a group known as Gay Women's Group-later renamed radicalesbians — and their shift from gay liberation to women's liberation demonstrated that this group of lesbian feminists were more aligned with women's liberation and feminism, than with 'mixed lesbian and gay politics'.$^{94}$ In the July 1973 issue of the $M W L N$, a small notice stated that the Gay Women's Group now met at the WLC every Tuesday at $8 \mathrm{pm}$ to discuss 'theory and action'. The meetings were open to 'all interested women' and the group intended to run 'women's dances ... in order to raise some money for the radicalesbian conference'. ${ }^{95}$ A group report that outlined the purpose of Gay Women's Group was published in the August 1973 issue of the $M W L N .{ }^{96}$ A side note published with this report contended that women from the Gay Women's Group were 'always at the forefront of feminist action' in 1973 and at 'recent demonstrations gay women have been quite a large proportion of the demonstrators'..$^{97}$

In 1974, the women at 16 Little La Trobe Street were forced to move out and in to 50 Little La Trobe Street. While I have thus far been unable to locate a description of the interior or exterior of this building, Taylor points out that this building was located directly opposite the Commonwealth Building where, five years prior, D'Aprano had chained herself in protest. In the two years since the WLC had first formed, the

91 Ibid.

92 Ibid. Archive file no. 305.4209945 WOME, University of Melbourne Archives, Melbourne.

93 Anon, 'Gay Sisters', Melbourne Women's Liberation Newsletter, May 1973, 7.

94 Jennings, 'Creating Feminist Culture', 89. Archive file no. 305.4209945 WOME, University of Melbourne Archives, Melbourne.

95 Chris, 'Gay Women's Group', Melbourne Women's Liberation Newsletter, July 1973, 10A. Archive file no. 305.4209945 WOME, University of Melbourne Archives, Melbourne.

96 Anon, 'Group Report: Gay Women's Group', Melbourne Women’s Liberation Newsletter, August 1973, 9.

97 Ibid. 
tensions and conflicts at the Centre were indeed escalating. Taylor wrote that the debate of whether or not to let men into the WLC was reignited when two men walked into the WLC 'one Saturday'. This debate seemed to revolve around the issue of whether or not the women-only place would be 'spoiled' by men and whether men could use 'one small section' of the WLC. ${ }^{98}$ Other issues were in relation to 'control' and the politics within the WLC, as well as issues relating to money. In 1976, the WLC moved once again to 100 Lonsdale Street. The building at 100 Lonsdale Street was described as a 'relatively small space' and was one of three terrace buildings. ${ }^{99}$ Eventually, the women's liberationists would rent all three buildings: one terrace house operated as the WLC, another as a rape crisis centre and the third was where Sybylla Press operated from. ${ }^{100}$

By this time, Taylor contends that the WLC had become an 'essential and integral part of the WLM as a whole, providing the necessary meeting space and focusing of political theory and action', but concedes that issues and conflicts had also increased. ${ }^{101}$ Taylor also believed that 'suburban women would feel so ill at ease on their first visit, that they may not face repeating the experience'. ${ }^{102}$ By 1976 , it is evident that D'Aprano felt that the tension between heterosexual and lesbian feminists at the WLC had reached a point that required her intervention, which she expressed in the form of a letter to the $M W L N$.

\section{Zelda D'Aprano's Letter}

In April 1976, the MWLN printed D'Aprano's letter, which expressed her concern about the increasing number of lesbian feminists at the WLC and the increasing visibility of lesbian feminists in the WLM in Melbourne. A reply to D'Aprano's letter was published in the same issue and was written by a woman named Maureen. She wrote that despite being a 'relative newcomer to the Centre', she felt that the meetings were 'friendly and relaxed', and that 'if straight women are put off by other women showing their affection at GMs, then it is they that have the

\footnotetext{
98 Taylor, Brazen Hussies, np.

99 Ibid.

100 Ibid.

101 Ibid.

102 Ibid. Archive file no. 305.4209945 WOME, University of Melbourne Archives, Melbourne.
} 
problem-it's not the lesbian's fault'. However, Maureen had observed that lesbian and heterosexual feminists were 'super sensitive to the differences' between the two groups. ${ }^{103}$

In her letter, D'Aprano contended that the General Meetings at the WLC had predominantly been attended by heterosexual women. ${ }^{104}$ She felt that the increase in visible lesbian feminists was upsetting to heterosexual feminists and that their presence changed the atmosphere, or sense of place, of the General Meetings. ${ }^{105}$ D'Aprano seemed to be particularly vexed by the way that lesbian feminists changed partners and lovers regularly, kissed at General Meetings and 'huddle[d] together in couple situations'. ${ }^{106}$ Furthermore, D'Aprano attributed the 'inner turmoil that seems to be seething in and around' the WLC to the presence of lesbian feminists. She claimed that lesbian feminists were making heterosexual feminists feel 'ill at ease' and had 'ceased speaking freely of their experiences with men'. ${ }^{107}$ Ultimately, it seems that, for D'Aprano, the increasing visibility of lesbian feminists at the WLC had crossed a line.

Boundaries, explains Linda McDowell, are an important factor to consider when analysing place and space. McDowell contends that boundaries are socially and spatially constructed. Boundaries, and those who uphold them, stipulate who belongs and who may be excluded. ${ }^{108}$ Acceptable behaviour within the boundaries that define places and spaces can depend upon a person's gender, age, class, sexual orientation and ethnicity. ${ }^{109}$ D'Aprano believed that the General Meetings at the WLC were predominately attended by heterosexual feminists, which suggests that the boundaries of the WLC were dependent on heteronormativity, thus she would have perceived the kissing and cuddling between lesbian feminists as breaking the rules of this heteronormative space. D'Aprano's shock at the observable increase in lesbian feminists at the WLC echoes Wilkens's research findings: that her participants 'did not express the same sense of belonging or safety' when their meeting place was shared by other

103 Maureen, 'A Reply to Zelda D’Aprano's “Sisters Speak”, Melbourne Women's Liberation Newsletter, April 1976, 3.

104 D’Aprano, 'Sisters Speak', 2.

105 D’Aprano, 'Sisters Speak', 1-2.

106 D’Aprano, 'Sisters Speak', 3.

107 Ibid.

108 Linda McDowell, Gender, Identity \& Place: Understanding Feminist Geographies (Cambridge: Polity Press, 1999), 4.

109 Ibid., 4, 11. 
groups. ${ }^{110}$ This is evident in D'Aprano's observation that heterosexual feminists had stopped speaking freely about their experiences with men and that while lesbian feminists may have felt safe to express themselves and their feelings for each other at the WLC, D'Aprano contended that heterosexual feminists no longer felt safe to talk about their experiences with men, or felt safe to 'express' themselves because she believed that heterosexual women felt 'intimidated' by lesbian feminists. ${ }^{111}$

Another concern that D'Aprano expressed was the joint mailout of Lesbian News and the MWLN. She questioned whether 'dissipating our women's energy' was worth it just to 'save a few dollars', which seems to demonstrate D'Aprano's concern for the longevity of the WLM in Melbourne, as she feared that the joint mailout would deter new women from joining the WLM. ${ }^{12}$ However, D'Aprano also believed that 'eighty percent of women in society are hetero' and asked 'what is wrong with our centres when these women feel alienated'. ${ }^{113}$ D'Aprano's belief that heterosexual women-like herself-made up the majority of women in Australian society and her concern over the safety of heterosexual women's liberationists at the WLC can be interpreted as an attempt to invoke safety in order to maintain the status quo and to 'silence the voices' of lesbian feminists. ${ }^{114}$ In doing so, D'Aprano reinforced the same homophobic attitudes that permeated Australian society during the 1970s in the WLC and demonstrated that her catchcry that 'all women could enter' the WLC did not seem to extend to lesbians. ${ }^{115}$

Contemporary scholars have described the quintessential hallmark of a women's liberation safe space as separatist and women-only. In her autobiography, D'Aprano reflected that 'all women who formed groups in the early years of the movement always found themselves confronted with the argument that men should be allowed to attend the meetings'. ${ }^{116}$ The women's liberationists and feminists who cultivated and operated out of the WLC were engaged with debates over separatism. These debates seemed to have been sparked when men attempted to enter the centre. In doing so, these men had attempted to physically cross the boundary

110 Wilkens, 'The Significance of Affinity Groups', 31.

111 D'Aprano, 'Sisters Speak', 3.

112 Ibid.

113 Ibid., 2.

114 Carter, 'Teaching with Trauma'.

115 D’Aprano, 'Sisters Speak', 1.

116 D’Aprano, Zelda, 155. 
into the women-only place. Some women, like Taylor, were adamant that the WLC was a women-only place, while others, like Alice, took a less militant approach to men. Another point of contention that fuelled the tension between heterosexual and lesbian feminists was the split between their private and political lives. For lesbian feminists, there was no divide between their political and private lives as lovers or partners could attend feminist meetings and activities. In contrast, heterosexual feminists were 'divided in their loyalties between the man at home and the Sisters in the Centre'. ${ }^{117}$ For lesbian feminists who lived separatist lives, the WLC could be seen as part of their attempt to live separate from men in order to gain their autonomy away from objectification and sexism. For women's liberationists who were not living separatist lives, the WLC can be interpreted as a separate space that could provide these women with 'temporary liberation from various social constraints' and as a place where they could plan and 'forge new political effectiveness within a broader public world'. ${ }^{118}$ In addition, while D'Aprano contended that heterosexual feminists felt uncomfortable with the 'anti-male' leanings that she believed lesbian feminists were bringing into the WLC, she also expressed her disapproval of the masculine clothing that lesbian feminists wore and wrote that she refused to 'emulate men whatsoever'. ${ }^{119}$ D'Aprano's criticism demonstrated that the way that separatism, or 'women-only', was interpreted in the WLC was context-specific; that heterosexual women who had separatist leanings, or who wanted to create a separate space, were refusing to act like men, while lesbian feminists who practised separatism were perceived as anti-male.

In applying spatial analysis to D'Aprano's letter, we can recognise how notions of safety and separatism were understood and articulated within the place and space of the WLC, which then helps us to understand how these notions contributed to the tensions and conflicts between heterosexual and lesbian feminists. In following the activity of women's liberationists and lesbian feminists after the publication of D'Aprano's letter, I argue that a spatial approach can help us to reconceptualise conflict as constructive to the WLM in Melbourne. ${ }^{120}$

117 Taylor, Brazen Hussies, np.

118 Enke, 'Smuggling Sex Through the Gates', 637-38.

119 D’Aprano, 'Sisters Speak', 1.

120 Carter, 'Teaching with Trauma', np. 


\section{Conflict as Constructive}

In July 1976, lesbian feminist Sue Jackson put forward a 'controversial' motion at a General Meeting at the WLC. Jackson felt that the WLM in Melbourne had stopped 'functioning [as] a political organisation' and that the WLC should be managed by a 'coalition of women' rather than continue with the current management structure. ${ }^{121}$ Taylor has recorded that over 100 women attended the 'special meeting' to discuss Jackson's motion. ${ }^{122}$ While the majority of women reportedly voted against Jackson's motion, this did not stop the WLC from closing in $1978 .{ }^{123}$ In place of the WLC, the Women's Cultural Palace opened in December 1978 and was located at 74 Moor Street, Fitzroy. ${ }^{124}$ The Coordinating Committee and the General Meetings were also abolished and were replaced by the Caretaker Group whose responsibilities were limited to overseeing the sub-renting of the rooms to various 'women's groups'. ${ }^{125}$ The Caretaker Group was part of a new 'management structure' that was designed to enable the 'collection of autonomous groups to cohabitate successfully'. ${ }^{126}$ In addition, a 'management collective', or a 'queen's council', was 'set up with one representative from each group that rents a room, and one representative from the caretakers group' who planned to meet monthly, and ensured that every group could have a say in decisions. ${ }^{127}$ While the Women's Cultural Palace operated similarly to the WLC in the way that it functioned as a central meeting place for the WLM in Melbourne, women's liberationists and lesbian feminists ultimately wanted to 'create an alternative to the old idea' of the WLC. ${ }^{128}$

\section{Conclusion}

In this paper, I have demonstrated that a spatial approach can help us to better understand how notions of safety and separatism contributed to the tensions and conflict between heterosexual and lesbian feminists

\footnotetext{
121 Taylor, Brazen Hussies, np.

122 Ibid.

123 Ibid. Archive file no. 305.4209945 WOME, University of Melbourne Archives, Melbourne.

124 Jean Taylor, Stroppy Dykes, 20, 28; Anon, 'Women's Cultural Palace', Melbourne Women's Liberation Newsletter, December 1978, 18.

125 Anon, 'Women's Cultural Palace', 18.

126 Ibid.

127 Ibid.

128 Ibid.
} 
at the WLC in Melbourne. In drawing on safe space scholarship and in examining the way that women's liberationists and lesbian feminists had cultivated their places and spaces, I have broadened understandings of the heterosexual-lesbian split in the WLM in Melbourne and have also contributed a new perspective to this history by recognising the way that heterosexual and lesbian feminists attempted to resolve their differences through the creation of the Women's Cultural Palace. Ultimately, I suggest that in asking different questions of the feminist past, we can broaden our understanding of the WLM in Australia. 
This text is taken from Lilith: A Feminist History Journal: Number 27, published 2021 by ANU Press, The Australian National University,

Canberra, Australia.

doi.org/10.22459/LFHJ.27.06 